Virginia Commonwealth University vCU Scholars Compass

Recovering a "Lost" Story Using Oral History: The United States Supreme Court's Historic Green v. New Kent County, Virginia, Decision

Jody L. Allen

College of William and Mary, jlalle@wm.edu

Brian J. Daugherity

Virginia Commonwealth University, bjdaugherity@vcu.edu

Follow this and additional works at: http://scholarscompass.vcu.edu/hist_pubs

Part of the Legal Commons, Public History Commons, and the United States History Commons

(C) 2006 Oral History Association

Downloaded from

http://scholarscompass.vcu.edu/hist_pubs/14

This Article is brought to you for free and open access by the Dept. of History at VCU Scholars Compass. It has been accepted for inclusion in History Publications by an authorized administrator of VCU Scholars Compass. For more information, please contact libcompass@vcu.edu. 


\section{“Recovering a 'Lost' Story Using Oral History: The United States Supreme Court's Historic Green v. New Kent County, Virginia, Decision”}

This is a pre-copyedited, author-produced PDF of an article accepted for publication in Oral History Review following peer review. The version of record, Jody Allen and Brian Daugherity, "Recovering a 'Lost' Story Using Oral History: The United States Supreme Court's Historic Green v. New Kent County, Virginia, Decision", Oral History Review (2006) 33(2): 25-44 is available online at: doi: $10.1525 /$ ohr.2006.33.2.25 
Jody Allen \& Brian Daugherity

Department of History

The College of William \& Mary

\section{Introduction}

In 2000 the National Park Service published a theme study titled "Racial Desegregation in Public Education in the United States.” Authorized by Congress, the study surveyed sites across the country "that best exemplify and illustrate the historical movement to provide for a racially nondiscriminatory education." ${ }^{\text {Two of the sites }}$ investigated were the George W. Watkins School and the New Kent School, both located in rural New Kent County, Virginia. In 1964, these two schools, one black and one white, set the stage for what would be one of the most important U.S. Supreme Court decisions since Brown v. the Board of Education. ${ }^{2}$

The story behind the case intrigued Dr. John Sprinkle, a Virginia native and Supervisory Historian at the National Park Service. It was fascinating not only for its importance in terms of U.S. school integration, but perhaps more so because no one knew

\footnotetext{
${ }^{1}$ Waldo Martin, Vicki Ruiz, Susan Salvatore, Harvard Sitkoff, and Patricia Sullivan. Racial Desegregation in Public Education in the United States Theme Study (Washington, DC: National Park Service, 2000).

2 The National Park Service study refers to Green as the "most important [Supreme Court] decision regarding school desegregation since Brown." See Martin, Ruiz, Salvatore, Sitkoff, and Sullivan, Racial Desegregation in Public Education in the United States, 91. The Encyclopedia of Civil Rights in America notes the Green decision "did more to advance school integration than any other Supreme Court decision since Brown v. Board of Education.” See David Bradley and Shelley F. Fishkin, eds., The Encyclopedia of Civil Rights in America (Armonk, NY: Sharpe Reference, 1998), vol. 2, 411.
} 
much about the decision. ${ }^{3}$ Together, Sprinkle and his staff decided that the Green case deserved additional looking in to. It would make an excellent addition to the Park Service's nationally recognized education program, Teaching With Historic Places. ${ }^{4}$

To research the case and develop a lesson plan for schoolteachers nationwide to address the Green case, Sprinkle and the Park Service applied for and received a grant from the Virginia Foundation for the Humanities and Public Policy (VFHPP) in Charlottesville, Virginia. At Sprinkle's request, Professor James Whittenburg, Chair of the History Department at nearby William \& Mary, contacted three graduate students interested in civil rights to take part.

These doctoral candidates, authors Jody L. Allen and Brian J. Daugherity, along with Sarah Trembanis, worked with New Kent High School students and a variety of individuals involved in the Green lawsuit to complete the lesson plan. The group consulted newspaper and county records, interviewed participants, and pieced together the little-known story behind this historic decision. The lesson plan, completed in 2001,

\footnotetext{
${ }^{3}$ A 2001 National Park Service-sponsored nomination to have the schools involved in the Green case designated as National Historic Landmarks [approved August, 2001] noted that the Green case is "much less well known than Brown." See Susan Cianci Salvatore, "New Kent School and George W. Watkins School" (New Kent County, Virginia) National Historic Landmark Nomination, Washington, D.C.: U.S. Department of the Interior, National Park Service, 2001.

${ }^{4}$ Created in 1991, Teaching with Historic Places is a branch of the National Park Service whose goal is to help educators teach their students about sites in the National Registry of Historic Places. The two schools involved in the Green case were added to the Registry in 2001.
} 
was posted on the Teaching With Historic Places web site and can be used by teachers all over the world to educate students about this little-known but important case. ${ }^{5}$

With this initial phase of the project completed, the authors decided to continue working on the New Kent story. Over the course of the next several years, we obtained additional grant funding and conducted an oral history project related to the Green case and school desegregation in New Kent County, hoping that our work might form the basis for a future documentary film on the Green case. ${ }^{6}$ Partnering with a local video production company, we recorded thirteen interviews on audio and digital videotape in 2002. Interviews were conducted Dr. Calvin Green (the lead plaintiff), State Senator Henry L. Marsh III (former Virginia state NAACP attorney), retired Federal District Judge Robert R. Merhige (who oversaw the implementation of Green in central Virginia), and other parents, community leaders, and students connected to the case.

The following year we hired Hollywood-based scriptwriter David Essex to produce a "treatment" - meaning a detailed script outline — for the documentary film. The treatment, along with a 10-minute film trailer and additional interviews and archival research, then formed the basis for a 60-minute working film script. All of this work has persuaded us that this vitally important story—once told—will add a very important piece to the puzzle of school desegregation in the United States.

\footnotetext{
5 “Charles Green v. County School Board of New Kent County, Virginia” web site, produced for the National Parks Service, Teaching with Historic Places program. URL:

www.cr.nps.gov/nr/twhp/newkent.htm. Posted initially February 2003. Recently featured on the U.S.

Department of Education's web site.

${ }^{6}$ The documentary, titled "The Green Light: Fulfilling the Promise of Brown v. Board of Education," is in the final production stages, and we anticipate its completion in 2008 for the $40^{\text {th }}$ anniversary of Green. It is being produced by Reel Productions, Inc., with help from WCVE, The Community Ideas Stations (PBS).
} 


\section{Recovering a Lost Story}

Using oral history to study the civil rights era is a challenging but necessary endeavor. Simply put, the controversial nature of this time period adds to the complexities of oral history more generally. For example, individuals who supported segregation, or white supremacy, often refuse to be interviewed now, fearful that their past beliefs will negatively impact their public standing or others' opinions of themselves. Their hesitancy leaves scholars with fewer interviews of white segregationists and government officials than of civil rights activists - which limits our understanding of white actions and beliefs during Jim Crow. Individuals who agree to be interviewed also pose challenges for scholars. It is not unusual for interviewees to exaggerate their actions during the civil rights era, hoping to impart greater importance on themselves than deserved. Other interviewees take part in what Michael Hoberman has called "nostalgic utopianism," idealizing the past in comparison to the present and raising questions about the reliability of memory. ${ }^{7}$

Even with these considerations in mind, it is difficult to overstate the value of oral history in allowing scholars to better understand the civil rights era. Because evidence has been lost, misplaced, or destroyed over time — or because record keeping is often not a priority in the midst of social change — organizational and individual records of the civil rights era are in short supply. Indeed, participant's memories are sometimes the only existing evidence about a particular civil rights event or organization. That, combined

\footnotetext{
${ }^{7}$ Michael Hoberman, "High Crimes and Fallen Factories: Nostalgic Utopianism in an Eclipsed New England Industrial Town,” Oral History Review, vol. 28, no. 1 (Winter/Spring 2001), 17-41; Barbara Shircliffe, "We Got the Best of that World': A Case for the Study of Nostalgia in the Oral History of School Segregation,” Oral History Review, vol. 28, no. 2 (Summer/Fall 2001), 59-84.
} 
with a higher level of illiteracy among activists, and a tradition of storytelling among African Americans, suggest that oral history provides a more familiar, or comfortable, way of recovering the past for many civil rights activists. For these reasons and others, scholars turn to former activists - as well as the defenders of Jim Crow — to answer questions scholarship has left unanswered and to preserve memories and lessons from the era for future generations.

This story—-that of Green v. New Kent County—would be lost were it not for the memories of its participants. As Dr. Sprinkle found, the case is rarely mentioned in civil rights monographs or articles, and only a handful of scholars know the story behind the case. ${ }^{8}$ More importantly, the case was overshadowed in the late 1960s by other eventsincluding events in Vietnam, urban riots, and the assassinations of Martin Luther King, Jr., and Robert Kennedy. After nearly fifteen years of school desegregation news, the coming of true integration hardly fazed a nation wracked by violence and unrest, at home and abroad. To recover the story behind Green v. New Kent County, and to celebrate its importance in integrating the nation's schools, one must listen to the participants in this little-known but historic case. Their story is told here for the first time.

\section{Brown and the Southern Response}

\footnotetext{
${ }^{8}$ The case is not mentioned in many accounts of the era, and when mentioned it garners usually a brief mention. Those works that do mention the case tend to be more recent publications. The story behind the case has not yet been told. See Peter Irons, Jim Crow's Children: The Broken Promise of the Brown Decision (New York: Viking, 2002); David S. Cecelski, Along Freedom Road: Hyde County, North Carolina, and the Fate of Black Schools in the South (Chapel Hill: University of North Carolina Press, 1994); James T. Patterson, Brown v. Board of Education: A Civil Rights Milestone and Its Troubled Legacy (Oxford: Oxford University Press, 2001).
} 
Life in New Kent County in the mid-1950s was divided clearly by what W. E. B. Du Bois termed "the color line."9 As part of Virginia's "Black Belt," a rural region of roughly forty counties in southern and eastern Virginia with agricultural roots and large African-American populations, New Kent had seen little racial change since the early twentieth century. ${ }^{10}$ Like elsewhere in Virginia and the South, blacks and whites were raised and educated in separate schools, socialized in separate circles, and - when the time came-buried in separate cemeteries. Within this system-legitimized by the “separate but equal” doctrine of the U.S. Supreme Court's 1896 Plessy v. Ferguson decision, and supported by most southern whites-African-Americans lacked equal educational opportunities and suffered the insult of entering businesses through back doors, being called by their first name, and other indignities. As Calvin Green described life in New Kent County in the mid-20 2 th century, "You didn't [have] any trouble with other people as long as you were in your place. And as long they stayed in their place, there was no problems."11

This situation — and the Jim Crow era — supposedly came to an end in 1954. On May 17 of that year the U.S. Supreme Court handed down its famous Brown v. Board of Education decision, and blacks in New Kent County celebrated, as did blacks throughout the nation. Dr. George W. Watkins, a leading African-American educator and the

\footnotetext{
${ }^{9}$ W. E. B. Du Bois, The Souls of Black Folk (New York: Dover Publications, 1994), Introduction and Chapter 1.

${ }^{10}$ For more on the Black Belt, see J. Harvie Wilkinson III, Harry Byrd and the Changing Face of Virginia Politics 1945-1966 (Charlottesville: University Press of VA, 1968), 114-116.

${ }^{11}$ Calvin C. Green, interview with the authors, December 17, 2002, for quote; Howard Ormond, interview with the authors, August 7, 2002.
} 
county's most respected black citizen explained the importance of the decision to eager students at New Kent's all-black George W. Watkins School. One of Dr. Watkins' former students described the scene, "he recognized the fact that this was going to be a very very important decision and he wanted the kids to hear it first hand and he talked a little bit about what the impact might be." ${ }^{\prime 2}$ Clearly the expectations of what Brown would accomplish were high. ${ }^{13}$ In the end, however, African Americans in New Kent, and nationwide, experienced few benefits from this historic ruling.

The reasons for the lack of change following the Brown decision were complex. First of all, the U.S. Supreme Court—recognizing the enormity of Brown—hesitated to force southern compliance with its 1954 mandate. When the Court's follow-up decree was handed down in 1955, it left the implementation of Brown to southern federal courts, failed to establish a timetable for desegregation, and included provisions allowing for desegregation delays. ${ }^{14}$ This was widely viewed as a setback for the National Association for the Advancement of Colored People (NAACP), which had argued for quick and complete southern school integration—by the fall of 1956 if possible. ${ }^{15}$ Although subsequent rulings expanded Brown to ban segregation outside of educationmost notably via the 1955-1956 Montgomery bus boycott—-the nation's highest court continued to minimize the impact of Brown in subsequent years. Historian J. Harvie

\footnotetext{
${ }^{12}$ Edward Pollard, interview with the authors, August 7, 2002.

${ }^{13}$ This was common throughout the nation. Wilkinson, Harry Byrd, 43, notes that on the day after the Brown decision Thurgood Marshall predicted that school segregation would be wiped out within five years.

${ }^{14}$ Brown v. Board of Education, Topeka, KS, 349 U.S. 294 (1955), also known as Brown II.

${ }^{15}$ Richard Kluger, Simple Justice: The History of Brown v. Board of Education and Black America's Struggle for Equality (New York: Vintage Books, 1975), 744-47.
} 
Wilkinson explains, "Where during this time, one might ask, was the United States Supreme Court? And the answer, not much exaggerated, is that from 1955 to 1968 , the Court abandoned the field of public school desegregation." 16

Unfortunately, no other branch of federal government picked up the slack. Civil rights activists — and scholars_- have long bemoaned President Eisenhower's lack of support for the high court's decision. ${ }^{17}$ A supporter of gradual change, and a Republican president who sought to increase support for his party in the largely Democratic South, Eisenhower refused to publicly endorse the decision. Later, the President referred to his appointment of Earl Warren — the author of the Brown decision—as Chief Justice of the U.S. Supreme Court as "the biggest damnfool mistake I ever made."18

The U.S. Congress also demonstrated little support for school desegregation. Because of seniority procedures, southern congressmen held chairmanships on key committees and wielded inordinate power. Long before the "Southern Manifesto" in March 1956, when 101 congressmen signaled their opposition to Brown, it was clear that southerners in Congress would strongly_ and effectively_oppose efforts to involve the legislature in the enforcement of Brown in the South. ${ }^{19}$

\footnotetext{
16 J. Harvie Wilkinson III, From Brown to Bakke: The Supreme Court and School Integration: 1954-1978 (Oxford: Oxford University Press, 1979), 61. Wilkinson notes that Green v. New Kent County (1968) ended this era of abandonment.

17 Wilkinson, From Brown to Bakke, 24. Calvin C. Green, interview with the authors, November 2, 2001.

${ }^{18}$ Harvard Sitkoff, The Struggle for Black Equality, revised edition (New York: Hill and Wang, 1993), 2425; Irons, 201. Warren, for his part, was extremely upset by Eisenhower's lack of public support for the ruling; see Wilkinson, From Brown to Bakke, 24

${ }^{19}$ Sitkoff, 25.
} 
In the end, it was Supreme Court Justice Felix Frankfurter who most presciently described the school desegregation process in the later 1950s and early 1960s. During the 1953 Supreme Court debate over Brown, Frankfurter had warned, “'Nothing could be worse from my point of view ... than for this Court to make an abstract declaration that segregation is bad and then have it evaded by tricks.",20

The "tricks" were carefully devised in Virginia. Following Brown, Virginia led the way as the South sought to delay public school desegregation. ${ }^{21}$ The most powerful figure in state politics, U. S. Senator Harry F. Byrd, Sr., declared: “'Let Virginia surrender to this illegal demand ... and you'll find the ranks of the other southern states broken.... If Virginia surrenders, if Virginia's line is broken, the rest of the South will go down, too."”22 Openly defying the Supreme Court, Byrd coined the term "Massive Resistance" to inspire an opposition movement among political leaders throughout the South. In Virginia, Massive Resistance led to an amendment to the state constitution that granted money for private-school tuition for any student assigned to a desegregated school, a General Assembly "Resolution of Interposition" in 1956, and numerous laws attacking the NAACP and other supporters of integration. ${ }^{23}$ At its height in 1958, this

\footnotetext{
${ }^{20}$ Wilkinson, From Brown to Bakke, 24.

${ }^{21}$ Here I refer to the South as the 11 former Confederate states. Michael Lassiter and Andy Lewis, The Moderates' Dilemma: Massive Resistance to School Desegregation in Virginia (Charlottesville: University Press of Virginia, 1998), X; Benjamin Muse, Virginia’s Massive Resistance (Bloomington: Indiana University Press, 1961), 159.

${ }^{22}$ Wilkinson, Harry Byrd, 156.

23 The General Assembly is Virginia's state legislature, initially incorporated as the House of Burgesses in 1619. In the summer of 1956, the Virginia legislature adopted twenty-three laws aimed at preserving
} 
opposition also led Governor J. Lindsay Almond, Jr., to close the schools in three Virginia localities rather than allow them to be desegregated by federal court orders. ${ }^{24}$

For its part, the NAACP remained the primary proponent of school desegregation in the nation. ${ }^{25}$ Utilizing its membership, particularly its southern branches and state offices (known as State Conferences), the NAACP National Office doggedly sought to

school segregation in the Commonwealth; James H Hershman, Jr., "A Rumbling in the Museum: The Opponents of Virginia's Massive Resistance," (Ph.D. dissertation, University of Virginia, 1978), 208-210; Robbins L. Gates, The Making of Massive Resistance: Virginia's Politics of Public School Desegregation, 1954-1956 (Chapel Hill: The University of North Carolina Press, 1962), 184; Papers of the NAACP, Part 20, reel 12, "Acts of Special Session of General Assembly of Virginia (Passed September 29, 1956), antiNAACP legislation".

${ }^{24}$ Hershman, 304; Gates, 210; Robert A. Pratt, The Color of Their Skin: Education and Race in Richmond, Virginia, 1954-89 (Charlottesville: University Press of Virginia, 1992), 9-10. These localities were Warren County, in the northern part of the state, Charlottesville, and Norfolk. The schools remained closed for roughly five months, before being reopened by state and federal court orders.

${ }^{25}$ Numerous individuals have recognized that the NAACP's activities in the post-Brown years have not received adequate scholarly attention, and documenting its actions is one goal of this essay. As Historian Charles Eagles writes in the November 2000 issue of the Journal of Southern History, "the larger stories of the NAACP as well as its Legal Defense and Educational Fund, especially after the school desegregation cases, have not been told (633)." In Race and Democracy: The Civil Rights Struggle in Louisiana, 1915 1972 (Athens: University of GA Press, 1995), historian Adam Fairclough concurs. He writes: "The NAACP is, paradoxically, the most important but also the least studied of the civil rights organizations (XIV)." There is a related lack of scholarship concerning the NAACP's activities in Virginia during the same era. In their 1998 study, The Moderates' Dilemma, historians Matthew Lassiter and Andrew Lewis write, "Many important aspects of African-American history during the civil rights era in Virginia remain unexplored by scholars, including the activities of the state and local branches of the NAACP... (206)." 
bring about the implementation of Brown v. Board in the later 1950s and 1960s. ${ }^{26}$ The Virginia State Conference, the largest and strongest southern unit of the Association, played a key role in this process. ${ }^{27}$ Its legal staff had argued many of the 1940s school “equalization” cases, which forced Virginia to set aside nearly $\$ 50$ million dollars for black schools and paved the way for the assault on segregation itself, as well as Davis v. Prince Edward County, one of the five school desegregation cases which made up the original Brown decision. ${ }^{28}$

After a frustrating 18-month period during which it attempted to cooperate with southern school boards to bring about school desegregation, the NAACP resorted to widespread litigation to implement the Brown decision in early $1956 .{ }^{29}$ Following

${ }^{26}$ The National Office, based in New York City, included the Association's full-time staff and Board of Directors. It traditionally made the major policy decisions for the Association. Minnie Finch, The NAACP: Its Fight for Justice (Metchen, NJ: The Scarecrow Press, Inc., 1981), 20; Aldon Morris, The Origins of the Civil Rights Movement (New York: Free Press, 1984), 13.

${ }^{27}$ NAACP Papers, Library of Congress Manuscript Reading Room, Part III Box C158, Letter from Roy Wilkins to Dr. Tinsley, September 25, 1956; Muse, Virginia's Massive Resistance, 47; Andrew Buni, The Negro in Virginia Politics, 1902-1965 (Charlottesville: University Press of Virginia, 1967), 177.

${ }^{28}$ For more on the equalization campaign, see Kluger, 19, 214-217. Davis v. Prince Edward County 103 F. Supp. 337.

${ }^{29}$ Initially the Association overestimated the ease with which desegregation would be accomplished, and chose to refrain from litigation to bring about its implementation. Its program changed after some 18 months of minimal compliance and growing signs of southern intransigence. See Brian Daugherity, "The Role of the NAACP in the Campaign for School Desegregation in Virginia, 1954-1968," unpublished graduate seminar paper in author's possession. See also Papers of the NAACP, Supplement to Part 1 (1951-55), reel 10, "Resolutions Adopted, Education [1954 Annual Convention]", 1; Papers of the NAACP, Part 3 Series C, reel 14, "Memorandum to Emergency Regional Conference, from Roy Wilkins and 
NAACP National Office guidelines, legal action was undertaken that year in eight southern states completely resisting desegregation, including Virginia. In Virginia, lawsuits in Charlottesville, Arlington, Norfolk, and Newport News led to Governor Almond's 1958 school closings, and subsequently—after additional litigation and court orders - to the admittance of twenty-one black students into formerly all-white schools in Virginia for the first time in February 1959. ${ }^{30}$

The historic entrance of these black students into white schools, however, hardly foreshadowed the end of white opposition to desegregation in Virginia. Instead, this development prompted increased opposition to desegregation from white Virginians and the state government. Looking back in 1961, one white Virginia journalist wrote, "It is difficult to describe the intensity with which the NAACP was hated by white Virginians. ${ }^{31}$

\section{Tokenism}

"[I]n the tradition of the old guards, who would die rather than surrender, a new and hastily constructed roadblock has appeared in the form of planned and institutionalized tokenism. Many areas of the South are retreating to a position where they will permit a handful of Negroes to attend all-white schools.... Thus, we have advanced in some places from all-out, unrestrained resistance to a sophisticated form of delaying tactics, embodied in tokenism. In a sense, this is one of the most difficult problems that the integration movement confronts." 32

---- Martin Luther King, Jr., 1962

Thurgood Marshall, June 4, 1955", 5; Papers of the NAACP, Supplement to Part 1 (1956-60), reel 2,

"NAACP Press Release", January 3, 1956.

${ }^{30}$ Muse, 48. NAACP legal action prompted increased opposition on the part of white Virginians and the

Virginia state government. Current scholarship on Massive Resistance fails to acknowledge this influence, robbing African-Americans of agency and power in the midst of this important struggle.

${ }^{31}$ Muse, 48.

32 J. Harvie Wilkinson, 85. 
Following initial desegregation, school boards around Virginia (with the blessing of state government) developed plans to either prevent school desegregation outright, or to admit small numbers of black students into formerly white schools - the latter to prevent successful NAACP legal action but also avoid significant integration. For several years the state's Pupil Placement Board minimized the impact of Brown by assigning students to schools based on non-racial criteria which were designed to minimize desegregation, but in the end the most popular route was by developing local "freedom-of-choice" plans. These plans allowed students, or more often their parents, to select the school they wanted to attend by completing a pupil assignment form. By placing the burden of desegregation on blacks themselves, such plans minimized desegregation. They were, however, initially seen as an acceptable method of desegregation by the federal government. ${ }^{33}$

The result, in Virginia and throughout the South, was minimal school desegregation well into the 1960s. In the fall of 1964, ten years after the Brown decision, only two percent of southern black students attended school with white students. ${ }^{34}$ In

\footnotetext{
${ }^{33}$ On the acceptance of "freedom of choice" by federal courts into the late 1960s, see Title VI of the Civil Rights Act of 1964 and subsequent guidelines put forth by the Department of Health, Education, and Welfare [78 Stat. 246, 42 U.S.C. 2000c-d, 45 CFR 80.1-80.13, 181.1-181.76 (1967)]. See also Charles C. Green v. County School Board of New Kent County, Virginia, 391 U.S. 430 (1968). When compared to outright opposition to desegregation-Alabama and Louisiana allowed no school desegregation until 1965-“freedom of choice" plans, and token desegregation more broadly, represented an acceptable compromise to the courts. For a discussion of this, and also how "freedom of choice" limited of desegregation, see Irons, 195.

${ }^{34}$ J. Harvie Wilkinson III, From Brown to Bakke, 46. This statistic drops to far less than $1 \%$ if Tennessee and Texas are excluded.
} 
Virginia, less than five percent of the approximately 233,000 black public school students attended school with whites. ${ }^{35}$ In New Kent County, Virginia, the school board avoided even token desegregation, refusing to admit any black students to the white schoolsuntil local blacks took action on their own.

\section{The Green Light}

"'When this opinion is handed down, the traffic light will have changed from Brown to Green." ---- U.S. Supreme Court Justice William Brennan, 1968

Calvin Coolidge Green, meanwhile, had settled in New Kent County with his wife Mary, in 1956. A native of Essex and Middlesex counties, not far to the northeast, Green was a decorated veteran of the Korean War and a graduate of Virginia State College. ${ }^{37}$ In 1959, Green signed on as a science teacher in Richmond, Virginia; his wife Mary had already begun her career teaching Home Economics in New Kent County.

Shortly after the Green's moved to New Kent, Calvin became involved in the NAACP. In the late 1950s, he helped reorganize the local branch, creating a separate New Kent organization out of the joint New Kent-Charles City branch. In 1960 Green was elected president of the New Kent branch, a position he would hold for the next 16 years. Motivated by the outbreak of the sit-ins in February of that year, Green felt that

\footnotetext{
${ }^{35}$ Francis M. Wilhoit, The Politics of Massive Resistance (New York: George Braziller, 1973), 289 [Table

B]. The year for the Virginia statistic is also $1964 ; 5 \%$ amounted to approximately 12,000 black students.

${ }^{36}$ Brennan is referring to Charles C. Green v. County School Board of New Kent County, Virginia, 391

U.S. 430 (1968). James T. Patterson, Brown v. Board of Education: A Civil Rights Milestone and Its

Troubled Legacy (Oxford: Oxford University Press, 2001), 146.

${ }^{37}$ Calvin C. Green, interview with the authors and Sarah Trembanis, October 16, 2001. Virginia State

College, one of the few institutions of higher learning for blacks in Virginia at the time, is now known as Virginia State University.
} 
the time had come to press for change. As he later explained it, "I was seeking [so] that somebody further down the road would have some better opportunities than we had."38

For several years during the early 1960s, Green pressured New Kent County leaders to desegregate the schools, to no avail. ${ }^{39}$ County records show little inclination on the part of the School Board to consider Green's requests, even when coupled with the threat of legal action. Green lamented, "The school board had done nothing to try to implement ... the Brown decision in the early Sixties." 40

Instead, most blacks continued to be bused throughout the county to the George W. Watkins School, an all-black institution. Though staffed with a cadre of caring and professional educators, the Watkins School's facilities paled in comparison to those of the white schools. Howard Ormond, hired to teach at the Watkins School in 1967, recalled:

There was no comparison. Everything that G.W. Watkins had was minimal. I don't know exactly how much New Kent High School had at the time, but New Kent High School had a gym, they had football facilities and they had I think more than one coach at that particular time. G.W. Watkins only had one because the principal asked me to do that and they had a band ... but as far as an equal amount of equipment, supplies, materials, there is no comparison. They didn't even have a basketball goal at G.W. Watkins. ${ }^{41}$

\footnotetext{
${ }^{38}$ Calvin C. Green, interview with the authors, November 2, 2001.

${ }^{39}$ Calvin C. Green, interview with the authors, December 17, 2002; New Kent County School Board records, Regular Meeting minutes, July 6, 1964.

${ }^{40}$ Calvin C. Green, interview with the authors, December 17, 2002.

${ }^{41}$ Howard Ormond, interview with the authors, August 7, 2002. Ormond is now the principal of New Kent Middle School. It is worth noting that the value of New Kent's white school property in June 1953 stood at $\$ 198,575$; the value of the black school property was $\$ 32,600$ — see Richmond Times-Dispatch, May 18, 1954, 6.
} 
In 1964, however, the U.S. Congress re-entered the civil rights milieu. Pressured by non-violent direct action in the South, and encouraged by President Johnson after the assassination of President Kennedy, Congress passed a new civil rights bill in July 1964 . The Civil Rights Act of 1964, among other things, threatened to cut federal funding to school districts that failed to develop plans to integrate their schools. ${ }^{42}$

The NAACP immediately sought to employ this powerful new weapon in Virginia and other southern states. ${ }^{43}$ At a meeting in Richmond later that year, Green heard Virginia NAACP attorneys explain that they wanted to use the Act to force intransigent school boards to comply with Brown. New litigation was needed to do so. When the attorneys asked for individuals to sponsor lawsuits, Green volunteered. ${ }^{44}$ After this meeting, Green returned to New Kent County and initiated a petition drive among black residents. Within a short time, he had obtained 540 signatures and submitted the petition to the school board, urging it to integrate the county's schools as quickly as possible. Predictably, the board refused to comply. ${ }^{45}$

In response to this refusal, Green met with attorneys from the state NAACP and in early 1965 helped develop a lawsuit demanding that the school board integrate the county's schools. Charles C. Green v. County School Board of New Kent County,

\footnotetext{
${ }^{42}$ Cecelski, 32-33; Sitkoff, 154, 224.

${ }^{43}$ Calvin C. Green, interview with the authors and Sarah Trembanis, October 9, 2001.

${ }^{44}$ Calvin C. Green, interview with the authors and Sarah Trembanis, October 9, 2001.

${ }^{45}$ Calvin C. Green, interview with the authors, December 17, 2002.
} 
Virginia — filed in Green's youngest son's name—was initiated in the U.S. District Court for the Eastern District of Virginia in March $1965 .^{46}$

The filing of the lawsuit, as expected, provoked a strong reaction among New Kent County's white population. County leaders, as well as more conservative New Kent blacks, pressured Green to withdraw the suit. When Green refused, his wife's teaching contract was not renewed, ending her long-time involvement with the county's public schools and placing the family in financial jeopardy. Green explains, "I knew from history and other kinds of things that people who filed suits were in great danger and we soon, we found ourselves in it. We already knew that and when they did not give my wife a job it was a big financial burden for us. A great big financial burden for us. OK?... It gets rough ... when you lose a job and you've got obligations that are depending on having that job." 47 In general, threats and intimidation against blacks increased, and several local black leaders publicly declared that they would defend themselves in the event of physical attacks on themselves or their families. ${ }^{48}$

The lawsuit itself was developed and argued almost entirely by the lawyers of the Virginia State Conference of the NAACP. Several of Virginia's pre-eminent civil rights

\footnotetext{
46 The Virginia State NAACP initiated nearly identical lawsuits in other Virginia localities that spring; see Cynthia Kay Bechter, "How the Goochland County Public Schools Desegregated," Goochland County Historical Society Magazine, v. 27, (1995), 38-41 for one additional example. Calvin C. Green, interview with the authors, November 2, 2001, notes that such a suit was also filed in Middlesex County. Irons, 200, incorrectly identifies Charles Green as his father Calvin.

${ }^{47}$ Calvin C. Green, interview with the authors and Sarah Trembanis, October 9, 2001.

${ }^{48}$ Calvin C. Green, interview with the authors, November 2, 2001; Cynthia Gaines, interview with the authors, November 13, 2001.
} 
attorneys, including S. W. Tucker, Henry L. Marsh III, and Oliver White Hill, participated in the process. In the suit, NAACP attorneys noted that the county had not yet developed any desegregation plan, and that the schools remained one hundred percent segregated ten years after Brown. ${ }^{49}$ In 1966, however, Federal District Court Judge John Butzner ruled against them, and the following year so did the Fourth Circuit Court of Appeals. Both courts ruled that a hastily developed "freedom-of-choice" plan, issued by the New Kent school board in August 1965, satisfied the requirement that it begin integrating the county's schools. ${ }^{50}$

As the litigation process unfolded, blacks students transferred into the formerly all-white New Kent School under the county's new "freedom of choice” plan. One of the first African-American students to transfer was Cynthia Gaines, whose parents petitioned for her to attend the all-white New Kent School in 1966, seeking better academic and extracurricular opportunities for their daughter. Gaines' experiences shed light on the challenges of desegregating white schools, and offer clues as to why "freedom of choice" failed. $^{51}$

${ }^{49}$ Charles C. Green v. County School Board of New Kent County, Virginia, 391 U.S. 430 (1968).

${ }^{50}$ The County's “freedom of choice" plan was developed in response to the Green lawsuit and the 1964 Civil Rights Act; Irons, 200. To some degree these judicial losses were not unexpected, considering again that "freedom of choice" plans were considered acceptable by the federal government, as well as federal courts at that time; see footnote 32 above. The fact that black students had to petition for admittance to the white schools, a process that invited economic and physical reprisals, was not considered sufficient reason to rule against the plans. It is also worth noting that the Green case was initially paired with a similar case filed in adjacent Charles City County and the lower court decisions are listed as Bowman v. County School Board of Charles City County, Va., 382 F.2d 326.

${ }^{51}$ Ms. Gaines is currently the Chairperson of the New Kent County school board. 
Gaines herself was a plaintiff in the NAACP's 1965 lawsuit. Gaines' father, Nathaniel Lewis, was the president of the local Civic League, a voter-registration organization that worked closely with the county NAACP. It was this background and personality that allowed Gaines to succeed in what proved to be a trying situation. Looking back, Gaines described the situation:

At the high school, there was really no attempt by the students or teachers to make us fit in, so we were charged with making ourselves fit in. So I'll give you an example: the first year I was there I tried out for the girls basketball team, and I was the first black girl to ever play basketball for New Kent. But at that time the varsity team, the cheerleaders, and the girls team all rode on the same bus because we didn't have JV (Junior Varsity) girls way back then. But no one would sit by me on the bus the entire basketball season; I don't care if we went to Matthews [Virginia], Middlesex, Yorktown, for miles no one would sit by me on the bus. And they would sometimes sit three in a seat to keep from sitting by me on the bus, so after a while you just had to make things funny so you wouldn't be hurt. So I would cross my legs, stretch out on the seat put my suitcase up, and prop my feet up and just ride. ${ }^{52}$

In the end, "freedom of choice" did little to adjust the county schools' attendance patterns. Just over one hundred black students transferred to the New Kent School, leaving $85 \%$ of the County's black students at the Watkins School. Not a single white student chose to attend the Watkins School. ${ }^{53}$ Even the faculties and staffs of the two schools remained completely segregated. These statistics reflected the results of "freedom of choice" plans throughout the South, highlighting the fact that "freedom of choice" rarely led to significant school desegregation. ${ }^{54}$

\footnotetext{
${ }^{52}$ Cynthia Gaines, interview with the authors, November 13, 2001.

${ }^{53}$ Charles C. Green v. County School Board of New Kent County, Virginia, 391 U.S. 430 (1968); Irons, 200. The "freedom of choice" plan was adopted by the School Board on August 2, 1965.

${ }^{54}$ Charles C. Green v. County School Board of New Kent County, Virginia, 391 U.S. 430 (1968).
} 
After its loss in the Fourth Circuit Court of Appeals in 1966, the NAACP debated whether or not to risk a negative ruling by appealing the Green case to the U.S. Supreme Court. By that time, there were signs that the Court would be amenable to such a suit. ${ }^{55}$ As a test case to argue that current desegregation programs - including "freedom of choice"-were not working, Green had a lot to offer. Former NAACP attorney Henry L. Marsh III explains: "We had all these school cases, and we wanted to get a case to be the pilot case so the Supreme Court could really break the log jam... [New Kent] was simple because it had two schools.... The population [black and white] was about equal. It was a logical solution. We had strong plaintiffs in New Kent. Green, the president of the NAACP, was a strong leader. That's important ... so the people won't ... won't be intimidated. So New Kent was the logical choice." 56 The NAACP petitioned for, and was granted, a hearing before the U.S. Supreme Court.

The Supreme Court began hearing the case in October 1967, and oral arguments took place on April 3, 1968, the day before Martin Luther King's assassination. The NAACP's lawyers argued that the county's “freedom of choice" plan unfairly placed the burden of integrating the county's schools on blacks, counter to what the Supreme Court had mandated in its 1955 implementation decree. NAACP attorneys also argued that the

\footnotetext{
55 The Supreme Court continued its liberal lean under the leadership of Earl Warren; making it by the late 1960s "much closer to the positions of the NAACP and other civil rights groups." Former NAACP attorney Thurgood Marshall was also appointed to the Court in the fall of 1967. Circuit court rulings in the mid-1960s also suggested growing judicial impatience with "freedom of choice." See Irons, 200-202.

${ }^{56}$ Honorable Henry L. Marsh III, interview with the authors, November 25, 2002.
} 
county was deliberately maintaining a bi-racial school system by busing some black students 20 miles to the Watkins School, though the New Kent School was much closer. ${ }^{57}$

On May 27, 1968, more than fourteen years after the original Brown decision, the Supreme Court issued its decision in Charles C. Green v. County School Board of New Kent County, Virginia. Ruling in favor of the plaintiffs and the NAACP, the Court found that the county was operating a dual system of schools down to "every facet of school operations - faculty, staff, transportation, extracurricular activities and facilities." With regard to the county's "freedom of choice" plan, the Court noted "... it is relevant that this first step did not come until some 11 years after Brown I was decided and 10 years after Brown II directed the making of a "prompt and reasonable start."' Furthermore, "Rather than further the dismantling of the dual system, the ["freedom of choice"] plan has operated simply to burden children and their parents with a responsibility which Brown II placed squarely on the School Board."58 Instead, the Court now required school boards to affirmatively eliminate all vestiges of segregation, transforming Brown's prohibition of segregation into a requirement of integration — and later prompting

\footnotetext{
${ }^{57}$ Charles C. Green v. County School Board of New Kent County, Virginia, 391 U.S. 430 (1968). For more on the duty which Brown II was supposed to have placed on southern school boards to develop desegregation plans, see Brown v. Board of Education, Topeka, KS, 349 U.S. 294 (1955).

${ }^{58}$ Charles C. Green v. County School Board of New Kent County, Virginia, 391 U.S. 430 (1968); it is worth noting that Green did not ban "freedom of choice" plans outright; it simply required that school districts go beyond "freedom of choice" when those plans were not truly leading to integration.
} 
Supreme Court Justice William H. Rehnquist to refer to Green as a "drastic extension of Brown." ${ }^{, 59}$

Justice William J. Brennan, author of the unanimous opinion, explained: "The burden on a school board today is to come forward with a plan that promises realistically to work, and promises realistically to work now." The fact that the School Board had opened the doors of the former "white" school to black children and of the "black" school to white children only initiated the process needed to abolish its dual, segregated system. The Court ordered school boards to immediately "convert promptly to a system without a ‘white' school and a 'Negro' school, but just schools.",60

Whites in New Kent County quickly voiced their displeasure with the decision. A cross was burned on the lawn of the Watkins School. White teachers and administrators threatened to leave the county rather than teach in the black school, and a small exodus of students enrolled in nearby private, segregated schools. Still, there was no alternative for county leaders. Shortly after the decision, the School Board converted the Watkins

\footnotetext{
${ }^{59}$ Justice William H. Rehnquist in Keyes v. School District No. 1, Denver, Colorado, 413 U.S. 189 (1972). It was also Green that expanded the school integration struggle forcefully into the North, ordering districts nationwide to integrate their schools according to the new standard.

${ }^{60}$ Charles C. Green v. County School Board of New Kent County, Virginia, 391 U.S. 430 (1968); Waldo Martin, Vicki Ruiz, Susan Salvatore, Patricia Sullivan, and Harvard Sitkoff, Racial Desegregation in Public Education in the United States Theme Study (Washington, DC: National Park Service, 2000), 91; Kluger, 766.
} 
School into the New Kent Elementary School and shifted the county's high school students to the New Kent School, now officially the New Kent High School. ${ }^{61}$

The impact of the Green decision quickly spread far beyond the borders of New Kent County. Throughout the nation, school boards were ordered to re-fashion their schools to conform to the decision. In most cases, this meant abandoning "freedom of choice" plans in favor of more substantive measures, such as busing or zoning. ${ }^{62}$

Within only a few years, the nation witnessed the achievement of a key goal of the early Civil Rights Movement- the integration of the nation's public schools. Referring to Green, the National Park Service's year 2000 study of school desegregation in the United States notes: "The results were startling. In 1968-69, 32 per cent of black students in the South attended integrated schools; in 1970-71, the number was 79 per cent." ${ }^{63}$ Former NAACP attorney, Henry L. Marsh III, agrees: “That's when we had real meaningful desegregation--all over in 1968. Before we had the [Green] decision, desegregation was stymied because you only had desegregation where you had black applicants willing to run the gauntlet in white schools. After Green v. New Kent as long

\footnotetext{
${ }^{61}$ Howard Ormond, interview with the authors, August 7, 2002; Calvin C. Green, interview with the authors and Sarah Trembanis, October 9, 2001. In the process, the Watkins School was renamed New Kent Elementary School, apparently to ease the concerns of white parents whose children would be enrolled there. This practice appears to have been common in the South at that time.

${ }^{62}$ Henry L. Marsh III, interview with the authors, November 25, 2002; Bechter, "How the Goochland County Public Schools Desegregated,” 38-41. Busing was accepted by the high court in Swann v. Charlotte- Mecklenburg Board of Education, 402 U.S. 1 (1971).

${ }^{63}$ Waldo Martin, Vicki Ruiz, Susan Salvatore, Patricia Sullivan, and Harvard Sitkoff, Racial Desegregation in Public Education in the United States, 91. Calvin Green, interview with authors, December 17, 2002, talks about the implementation of Green in the Richmond, Virginia, public schools in 1970.
} 
as 'freedom of choice' was not working, it was unlawful. So [the U.S. Department of

Health, Education, and Welfare] HEW took that decision and implemented desegregation on a wide basis--before that decision it didn't happen, so that was a crucial case." ${ }^{\prime 64}$

\section{Conclusion}

Still, few civil rights scholars know the story behind the Green decision, and many still fail to recognize its importance. The case, its background, and its significance are among the lesser-known stories of African-American history. This lack of attention, and understanding, is partly the result of a lack of evidence regarding the case, and particularly the story behind the case - a story of African American perseverance to overcome long-held values and beliefs. To understand this story, one need turn to those who took part, and to listen as they recall their roles in one of the most important Supreme Court school integration cases in our nation's history.

\footnotetext{
${ }^{64}$ Honorable Henry L. Marsh III, interview with the authors, November 25, 2002. HEW was the precursor to today's U.S. Department of Education. Final italics added by the author. For the importance of Green, see also Wilkinson, From Brown to Bakke, 78.
} 